\title{
Karakteristik Fisikokimia dan Preferensi Cascara Terbuat dari Kulit Kopi Robusta var. Tugu Sari dan BP 42
}

\section{Physicochemical Characteristics and Preferences of Cascara Made from Robusta var. Tugu Sari and BP 42}

\author{
Nurhayati $^{* 1}$, Maria Belgis ${ }^{2}$, Danis Aprilia Neilasari ${ }^{3}$ \\ 1,2,3 Teknologi Hasil Pertanian, Universitas Jember \\ Jalan Kalimantan No. 37 FTP UNEJ Jember \\ 1\#nurhayati.ftpeunej.ac.id \\ 2danisprilya@gmail.com \\ 3maria.belgis@unej.ac.id
}

\begin{abstract}
Coffee pulp is a potential source of antioxidants and phenolic compounds, thus coffee pulp has the potential to be used as an ingredient a beverage Such as cascara tea. The aim fo this researc was to determine effect of difference varieties and pre-drying on physicochemical characteristic and consumer preference of cascara Robusta tea.This study used Factorial Completely Randomized Design (CRD) consisting of two factors, there were variety (A) and pre-drying process (B). Variety difference factor consists of two levels, namely A1 (Tugu Sari) and A2 (BP 42), while the pre-drying process consists of two levels, namely B1 (stripping before drying) and B2 (stripping after drying). Physicochemical data were analyzed using ANOVA $(\alpha=5 \%)$ and continued using DMRT while preference data were analyzed using Chi-square test $(\alpha=5 \%)$. Determination of the best treatment using qualitative descriptive with scoring analysis. The best treatment was Tugu Sari variety with stripping treatment before drying with overall preference value was preferred by panelists and total polyphenol value of $10.65 \mathrm{GAE} / \mathrm{mL}$; antioxidant activity of $70,12 \%$; caffeine level of $1,25 \%$; total titrated acid of $2,57 \%$; $\mathrm{pH}$ of 3,76; specific gravity of $1,042 \mathrm{mg} / \mathrm{mL}$; total dissolved solids of $2{ }^{\circ} \mathrm{Brix}$; brightness of $(\mathrm{L} *) 27,48$
\end{abstract}

Keyword: Caffeine, cascara, coffee, Robusta

\section{PENDAHULUAN}

Kopi Robusta merupakan tanaman kopi yang paling banyak ditanam di Indonesia. Salah satu daerah penghasil kopi yaitu di Kabupaten Jember, salah satunya di Desa Sidomulyo. Desa ini merupakan daerah penghasil kopi sebanyak 8.300,1 ton kopi dengan luas perkebunan kopi 777, $265 \mathrm{Ha}$, dengan jenis kopi Robusta salah satunya yaitu varietas kopi BP 42 dan kopi Tugu Sari.

Pengolahan kopi akan menghasilkan hasil sampingan yaitu kulit kopi. Kulit kopi merupakan sumber antioksidan dan senyawa fenolik potensial, sehingga kulit kopi berpotensi digunakan sebagai bahan pembuatan minuman teh cascara. Teh cascara merupakan teh yang dibuat dari kulit buah kopi Arabika maupun Robusta. Penelitian mengenai teh cascara yang telah dilakukan adalah dari kulit kopi Arabika, namun belum dilaporkan ada yang menggunakan kulit kopi Robusta. Kandungan senyawa fenolik dalam kulit kopi yang berasal dari perkebunan dan varietas yang berbeda akan bervariasi, selain itu proses pengolahan juga menunjukkan kandungan senyawa fenolik dan kafein yang sangat berbeda. Berdasarkan ulasan di atas perlu dilakukan penelitian pengaruh perbedaan varietas dan proses pra pengeringan untuk mengetahui karakteristik fisikokimia dan preferensi konsumen pada minuman teh cascara Robusta.

\section{METODOLOGI}

\section{A. Alat dan Bahan Penelitian}

Alat pembuatan teh cascara yaitu beaker glass, kompor, panci, dan spatula. Alat untuk analisis yaitu, 
Nurhayati, Maria Belgis, Danis Aprilia Neilasari. Karakteristik Fisikokimia dan Preferensi Cascara Terbuat dari Kulit Kopi Robusta var. Tugu Sari dan Bp 42

colour reader, $\mathrm{pH}$ meter, spektofotometer UV-Vis, thermometer, gelas ukur, neraca analitik, tabung reaksi, beaker glass, pipet mikro, vortex, corong pisah, pipet ukur, buret, erlenmeyer, pipet tetes, piknometer dan gelas sensori.

Bahan utama yang digunakan kopi Robusta varietas BP 42 dan Tugu Sari dengan umur petik 8-11 bulan dari masa pembungaan. Kopi diperoleh dari Perkebunan Kopi Desa Sidomulyo, Kecamatan Silo, Jember dan air. Bahan untuk analisis yaitu aquades, etanol PA, etanol 96\%, DPPH, Follin-Ciocalteau, larutan asam galat, $\mathrm{Na} 2 \mathrm{CO} 3$, indikator pp $1 \%$ kloroform, kafein, dan $\mathrm{NaOH} 0,1 \mathrm{~N}$.

\section{B. Tahap Penelitian}

Tahapan penelitian diawali dengan memetik kopi yang matang dengan umur petik 8-11 bulan dari masa pembungaan, kemudian disortasi. Selanjutnya dilakukan penimbangan menjadi dua bagian. Bagian pertama buah kopi dikupas menggunakan manual, bagian kedua buah kopi dibiarkan tidak dikupas. Tahap selanjutnya dilakukan pengeringan menggunakan sinar matahari sampai kering. Pembuatan teh cascara diawali perebusan dengan memanaskan 1 liter air hingga mendidih, kemudian ditambahkan kulit kopi kering sebanyak 100 g per liter air, selanjutnya dilakukan pengadukan selama 6,5 menit. Setelah ekstraksi dilakukan penyaringan sehingga didapatkan larutan teh cascara. Hasil ekstraksi digunakan sebagai bahan untuk pengujian fisikokimia dan uji preferensi.

\section{Rancangan Percobaan}

Penelitian ini menggunakan dua faktor yaitu varietas (A) dan proses pra pengeringan (B). Faktor perbedaan varietas terdiri dari dua taraf yaitu A1 (Tugu Sari) dan A2 (BP 42), sedangkan proses pra pengeringan terdiri dari dua taraf yaitu B1 (pengupasan kulit kopi sebelum pengeringan) dan B2 (pengupasan kulit kopi setelah pengeringan.

Pengolahan data pengujian fisikokimia dilakukan menggunakan analisa sidik ragam (ANOVA) dan uji beda nyata dilakukan dengan uji DMRT (Duncan's Multiple Range Test). Hasil uji preferensi dianalisis menggunakan Chi-square $(\alpha=$ $0,05)$ sedangkan perlakuan terbaik ditentukan secara deskriptif kualitatif dengan pemberian nilai.

\section{Analisis}

Teh cascara diuji secara fisik, kimia, dan preferensi. Uji fisikokimia meliputi total padatan terlarut (oBrix) (Nurhayati, 2019), pH (AOAC, 1995), total asam tertitrasi (AOAC, 1995), warna (lightness) (Hutching, 1999), uji antioksidan metode DPPH, kadar kafein metode spektrofotometri (Fitri, 2008), total polifenol metode follinciocelteau (Chun et al., 2003), pengujian preferensi (Kim dan O'Mahony, 1998 dalam Hasanah et al., 2014).

\section{HASIL DAN PEMBAHASAN}

\section{A. Total Padatan Terlarut}

Total padatan terlarut merupakan ukuran zat terlarut dalam air (baik zat organik maupun anorganik). Material-material yang tergolong dapat larut dalam air seperti karbonat, bikarbonat, klorida, sulfat, fosfat, nitrat, kalsium, magnesium, natrium, ion-ion organik, dan ion-ion lainnya. Total padatan terlarut teh cascara berkisar antara $2^{\circ}$ Brix sampai $3,33^{\circ}$ Brix. Nilai total padatan teh cascara ditunjukkan pada Gambar 1.

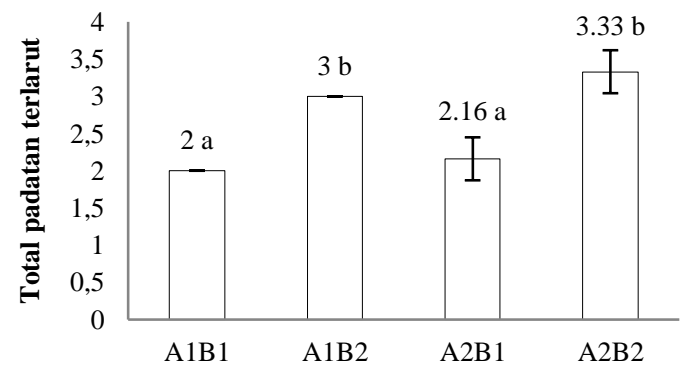

Gambar 1 Total padatan terlarut teh cascara dengan variasi varietas (A1: varietas Tugu Sari dan A2: varietas BP42) dan proses pra pengeringan (B1: pengupasan sebelum pengeringan dan B2: pengupasan setelah pengeringan)

Total padatan terlarut dengan nilai tertinggi yaitu pada teh cascara A2B2 dan terendah pada teh cascara A1B1. Perbedaan proses pra pengeringan berpengaruh nyata $(\alpha<0,05)$, namun perbedaan varietas tidak berpengaruh nyata terhadap total padatan terlarut teh cascara. Perlakuan B2 menunjukkan nilai total padatan terlarut lebih tinggi. Pada perlakuan ini pengupasan kulit kopi dilakukan setelah pengeringan dengan cara ditumbuk sehingga kulit tanduk (endocarp) pada kopi ikut menjadi sampel cascara, sehingga menyebabkan jumlah total padatan terlarut yang dihasilkan semakin meningkat.

Menurut Ardheniati [1], kandungan asam amino dan kafein juga dapat mempengaruhi nilai total padatan terlarut. Berdasarkan analisa total padatan terlarut sampel yang memiliki nilai paling tinggi yaitu teh cascara dengan varietas kopi BP 42. Hal ini sesuai dengan analisa kadar kafein bahwa teh cascara dengan varietas BP 42 memiliki nilai kadar kafein yang lebih tinggi sehingga nilai total padatan terlarutnya juga lebih tinggi.

B. pH Teh Cascara

Nilai $\mathrm{pH}$ berbanding terbalik dengan total asam, jika $\mathrm{pH}$ menunjukkan nilai yang rendah maka nilai keasaman biji kopi meningkat. $\mathrm{pH}$ teh cascara ditunjukkan pada Gambar 2.

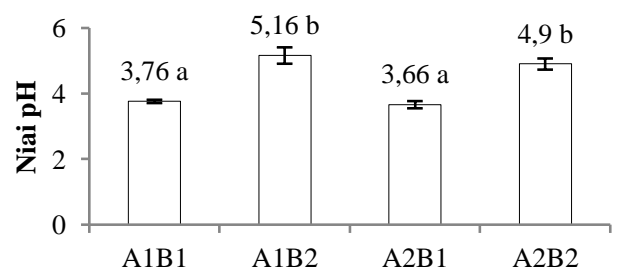

Gambar 2. $\mathrm{pH}$ teh cascara dengan perlakuan variasi varietas (A1: varietas Tugu Sari dan A2: varietas BP42) dan proses 
Nurhayati, Maria Belgis, Danis Aprilia Neilasari. Karakteristik Fisikokimia dan Preferensi Cascara Terbuat dari Kulit Kopi Robusta var. Tugu Sari dan Bp 42

pra pengeringan (B1: pengupasan sebelum pengeringan dan B2: pengupasan setelah pengeringan).

Variasi proses pra pengeringan berpengaruh nyata $(\alpha<0,05)$ terhadap $\mathrm{pH}$ teh cascara. Nilai $\mathrm{pH}$ yang terdapat pada teh cascara bergantung pada kandungan asam yang ada di dalam kulit kopi. Protocatechuic acid dan asam klorogenat adalah senyawa yang dominan di cascara yaitu sebesar 85,0 dan 69,6 mg/L Faktor lain yang menyebabkan $\mathrm{pH}$ teh cascara dengan perlakuan pegupasan sebelum pengeringan memiliki nilai $\mathrm{pH}$ yang lebih rendah karena dimungkinkan terjadinya fermentasi spontan oleh mikroorganisme yang ada di tangan pada saat proses pengupasan manual dengan tangan.

Nilai total asam tertitrasi pada perlakuan pengupasan sebelum pengeringan memiliki nilai yang lebih tinggi daripada sampel dengan perlakuan pengupasan kulit setelah pengeringan. Kadar asam berbanding terbalik dengan $\mathrm{pH}$ seduhan yaitu semakin rendah nilai total asam, maka nilai $\mathrm{pH}$ akan semakin meningkat karena jumlah total asam yang semakin sedikit. Hal ini sesuai dengan hasil analisa total asam tertitrasi yaitu sampel A2B1 memiliki nilai $\mathrm{pH}$ paling rendah sehingga memiliki nilai total asam tertinggi sedangkan sampel A1B2 memiliki $\mathrm{pH}$ tertinggi dan juga total asam yang terendah.

\section{Total Asam Tertitrasi}

Total asam tertitrasi teh cascara berkisar antara $1,84 \%$ sampai $2,85 \%$. Nilai total asam tertitrasi teh cascara ditunjukkan pada Gambar 3.

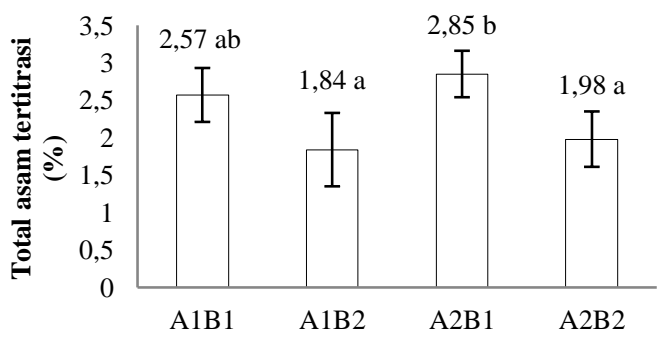

Gambar 3. Total asam tertitrasi teh cascara dengan perlakuan variasi varietas (A1: varietas Tugu Sari dan A2: varietas BP42) dan proses pra pengeringan (B1: pengupasan sebelum pengeringan dan B2: pengupasan setelah pengeringan).

Perbedaan proses pra pengeringan dan varietas berpengaruh nyata $(\alpha>0,05)$ terhadap total asam tertitrasi teh cascara. Total asam tertitrasi dipengaruhi oleh perbedaan kandungan asam klorogenat yang ada dalam setiap cascara. Asam klorogenat adalah senyawa fenolik yang dominan di cascara yaitu 69,6 $\mathrm{mg} / \mathrm{L}$ Heeger [3]. Proses pra pengeringan yang berbeda juga menyebabkan kandungan asam klorogenat pada setiap sampel berbeda. Senyawa asam klorogenat lebih rentan terhadap suhu tinggi karena sifatnya yang mudah terhidrolisis menjadi senyawa yang mudah larut dalam air dan keluar melalui uap panas. Oleh karena itu, pada perlakuan B2 memiliki total asam tertitrasi lebih rendah daripada perlakuan B1, dikarenakan lama pengeringan pada perlakuan B2 membutuhkan waktu yang lebih lama sehingga menyebabkan kandungan asam klorogenatnya menurun. Faktor lain yang menyebabkan kandungan asam klorogenat yang ada dalam setiap kulit kopi berbeda disebabkan oleh beberapa faktor yaitu karena faktor genetik, kultivar, praktek pengolahan penanaman oleh petani, iklim, jenis tanah, dan lingkungan sekitar.

Nilai total asam tertitrasi pada perlakuan pengupasan sebelum pengeringan memiliki pH yang lebih tinggi. Kadar asam berbanding terbalik dengan $\mathrm{pH}$ seduhan. Semakin rendah nilai total asam, maka nilai $\mathrm{pH}$ akan semakin meningkat karena jumlah total asam yang semakin sedikit. Hal ini sesuai dengan hasil analisa total asam tertitrasi yaitu sampel A2B1 memiliki $\mathrm{pH}$ yang terendah sedangkan nilai total asam tertinggi sedangkan sampel A1B2 memiliki $\mathrm{pH}$ tertinggi dan total asam yang terendah.

\section{Kecerahan ( $\left.L^{*}\right)$ Teh Cascara}

Kecerahan teh cascara ditunjukkan pada Gambar 4. Perbedaan proses pra pengeringan dan varietas berpengaruh nyata $(\alpha>0,05)$ terhadap kecerahan teh cascara.

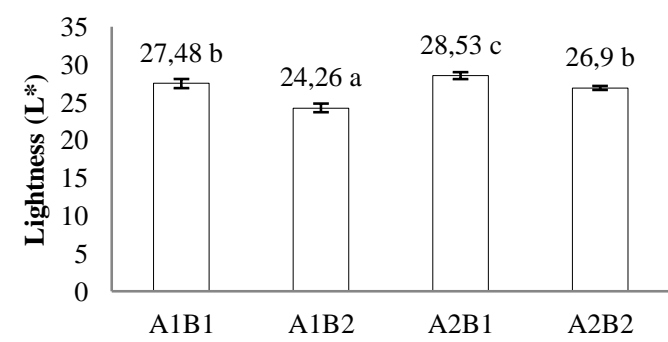

Gambar 4. Kecerahan $\left(\mathrm{L}^{*}\right)$ teh cascara dengan perlakuan variasi varietas (A1: varietas Tugu Sari dan A2: varietas BP42) dan proses pra pengeringan (B1: pengupasan sebelum pengeringan dan B2: pengupasan setelah pengeringan)

Teh cascara dengan perlakuan pengupasan kulit sebelum pengeringan memiliki nilai kecerahan yang lebih tinggi daripada perlakuan pengupasan kulit setelah pengeringan. Menurut Lestario et al [7] pada cascara terdapat $\alpha$ diketon yang menyebabkan warna coklat akibat penguraian antosianin pada kulit kopi selama proses pengeringan. Kulit kopi mengandung pigmen antosianin yang menyumbang warna merah pada kulit kopi. Menurut Lydia [9] Proses pengeringan dapat menyebabkab stabilitas warna antosianin menurun. Penurunan stabilitas warna antosianin karena degradasi antosianin dari bentuk aglikon menjadi kalkon dan akhirnya membentuk alfa diketon yang berwarna coklat. Perlakuan pengupasan kulit setelah pengeringan akan menyebabkan waktu pengeringan yang lebih lama sehingga menyebabkan warna kulit kopi semakin gelap. 
Nurhayati, Maria Belgis, Danis Aprilia Neilasari. Karakteristik Fisikokimia dan Preferensi Cascara Terbuat dari Kulit Kopi Robusta var. Tugu Sari dan Bp 42

\section{E. Total polifenol teh cascara}

Total polifenol teh cascara berkisar antara 10,21 $\mathrm{mg}$ GAE/mL sampai $11,8 \mathrm{mg}$ GAE/mL. Nilai total polifenol teh cascara ditunjukkan pada Gambar 5.

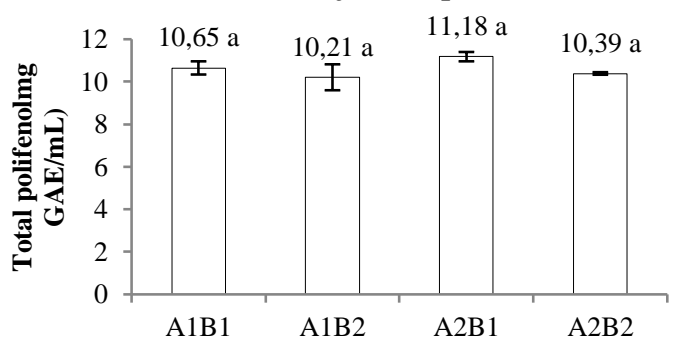

Gambar 5. Total polifenol teh cascara dengan perlakuan variasi varietas (A1: varietas Tugu Sari dan A2: varietas $\mathrm{BP} 42)$ dan proses pra pengeringan (B1: pengupasan sebelum pengeringan dan B2: pengupasan setelah pengeringan).

Perbedaan perlakuan proses pra pengeringan dan varietas tidak berbeda nyata $(\alpha<0,05)$ terhadap total polifenol teh cascara. Hal ini dikarenakan varietas yang digunakan adalah kulit kopi dengan jenis yang sama yaitu Robusta sehingga variasi varietas tidak berpengaruh nyata terhadap kandungan polifenol, selain itu proses pra pengeringan juga tidak dapat berpengaruh nyata dikarenakan pada akhirnya kulit kopi sama-sama dilakukan pengeringan dengan sinar matahari sehingga hasil total polifenolnya tidak berbeda nyata.

\section{F. Aktivitas Antioksidan}

Perlakuan variasi proses pra pengeringan berpengaruh nyata $(\alpha<0,05)$ terhadap aktivitas antioksidan teh cascara. Nilai aktivitas antioksidan ditunjukkan pada Gambar 6.

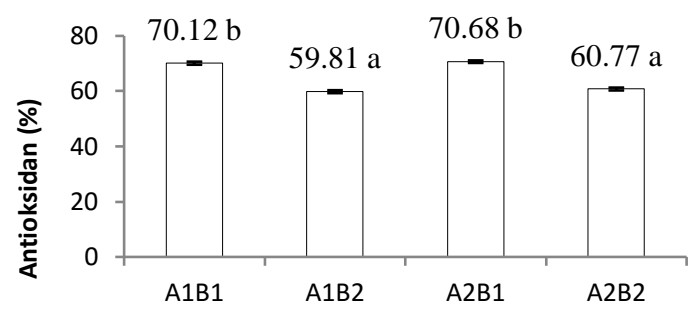

Gambar 6. Aktivitas antioksidan (\%) teh cascara dengan perlakuan variasi varietas (A1: varietas Tugu Sari dan A2: varietas BP42) dan proses pra pengeringan (B1: pengupasan sebelum pengeringan dan B2: pengupasan setelah pengeringan)

Aktivitas antioksidan teh cascara dengan perlakuan pengupasan kulit sebelum pengeringan memiliki nilai yang lebih tinggi. Hal ini dikarenakan perlakuan pengeringan cascara sebelum dikupas membutuhkan waktu yang lebih lama sehingga dapat menurunkan kemampuan antioksidan pada cascara. Aktivitas antioksidan akan semakin menurun dengan semakin tingginya suhu pengeringan yang digunakan selama proses pengolahan. Selanjutnya menurut Jacobo-Velaquez [5] senyawa fenolik adalah salah satu komponen penting yang mempengaruhi aktivitas antioksidan dalam bahan pangan. Semakin tinggi senyawa polifenol pada bahan maka aktivitas antioksidannya juga akan semakin tinggi. Ini berbanding lurus dengan analisa total polifenol yang dilakukan yaitu total polifenol tertinggi adalah teh cascara dengan perlakuan pengupasan kulit sebelum pengeringan.

\section{G. Kadar Kafein}

Kadar kafein teh cascara memiliki nilai berkisar antara $1,04 \%$ sampai $1,37 \%$. Grafik nilai kadar kafein ditunjukkan pada Gambar 7.

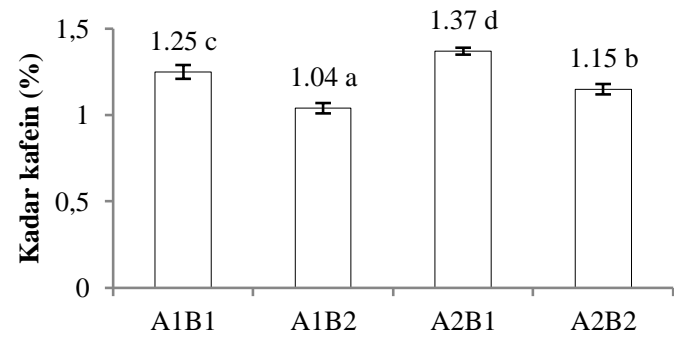

Gambar 7. Kadar kafein teh cascara dengan perlakuan variasi varietas (A1: varietas Tugu Sari dan A2: varietas BP42) dan proses pra pengeringan (B1: pengupasan sebelum pengeringan dan $\mathrm{B} 2$ : pengupasan setelah pengeringan).

Perbedaan proses pra pengeringan dan varietas berpengaruh nyata $(\alpha<0,05)$ terhadap kadar kafein teh cascara. Teh cascara dengan perlakuan pengupasan sebelum pengeringan menghasilkan nilai kadar kafein yang lebih. Hal ini dikarenakan pengupasan kulit setelah pengeringan membutuhkan waktu pengeringan yang lebih lama sehingga terjadi fermentasi yang lebih lama daripada fermentasi yang terjadi pada perlakuan pengupasan kulit sebelum pengeringan. Menurut Kurniawati [6], buah kopi mengandung karbohidrat $35 \%$, protein $5,2 \%$, serat $30,8 \%$ dan pulp atau daging buah yang melekat pada kulit buah kopi mengandung protein $8,9 \%$, gula $4,1 \%$, kandungan komponen-komponen inilah yang memungkinkan terjadinya fermentasi oleh mikroorganisme selama proses pengeringan terutama pengeringan lambat dengan sinar matahari. Menurut Londra [8], proses fermentasi mampu menurunkan kadar kafein, sehingga kadar kafein pada teh cascara dengan perlakuan pengupasan kulit setelah pengeringan menghasilkan kadar kafein yang lebih rendah.

\section{H. Warna Teh Cascara}

Persentase tingkat kesukaan panelis terhadap warna teh cascara dengan variasi varietas dan proses pra pengeringan dapat dilihat pada Tabel 1. 
Nurhayati, Maria Belgis, Danis Aprilia Neilasari. Karakteristik Fisikokimia dan Preferensi Cascara Terbuat dari Kulit Kopi Robusta var. Tugu Sari dan Bp 42

TABel I. Presentase TingKat KesukaAn Panelis DENGAN SCORE SANGAT TidAK SUKa HingGa SANGat Suka TERHADAP Warna TeH CASCARa DENGan VARIASI

\begin{tabular}{lcccc}
\multicolumn{5}{c}{ VARIETAS DAN } \\
\hline Perlakuan & $\begin{array}{c}\text { Agak } \\
\text { suka } \\
(\%)\end{array}$ & $\begin{array}{c}\text { Suka } \\
(\%)\end{array}$ & $\begin{array}{c}\text { Sangat } \\
\text { suka } \\
(\%)\end{array}$ & Jumlah (\%) \\
\hline A1B1 & 18 & 22 & 4 & 44 \\
AIB2 & 16 & 28 & 7 & 51 \\
A2B1 & 26 & 36 & 6 & 68 \\
A2B2 & 20 & 21 & 8 & 49 \\
\hline
\end{tabular}

Hasil uji Chi-square dengan taraf signifikansi 5\% menunjukkan bahwa nilai signifikansi warna teh cascara berbeda nyata. Teh cascara yang memiliki nilai agak suka sampai sangat suka tertinggi adalah sampel A2B1 yaitu 68\%. Hal ini menunjukkan bahwa panelis cenderung menyukai warna seduhan teh cascara yang tidak terlalu gelap. Perlakuan pengupasan sebelum pengeringan menyebabkan waktu pengeringan yang lebih singkat daripada perlakuan pengupasan setelah pengeringan. Kulit kopi mengandung pigmen antosianin yang menyumbang warna merah pada kulit kopi. Proses pengeringan dapat menyebabkan stabilitas warna antosianin menurun. Penurunan stabilitas warna antosianin karena degradasi antosianin [9].

\section{Aroma Teh Cascara}

Persentase tingkat kesukaan panelis terhadap aroma teh cascara dengan variasi varietas dan proses pra pengeringan dapat dilihat pada Tabel 2 .

TABel iI. Presentase TingKat KesukaAn Panelis Dengan Score Sangat Tidak Suka HingGa Sangat SuKa Terhadap Aroma Teh Cascara Dengan Variasi VARIETAs Dan Proses Pra Pengeringan

\begin{tabular}{ccccc}
\hline Perlakuan & $\begin{array}{c}\text { Agak suka } \\
(\%)\end{array}$ & $\begin{array}{c}\text { Suka } \\
(\%)\end{array}$ & $\begin{array}{c}\text { Sangat } \\
\text { suka (\%) }\end{array}$ & Jumlah (\%) \\
\hline A1B1 & 30 & 24 & 5 & 59 \\
AIB2 & 12 & 26 & 6 & 44 \\
A2B1 & 14 & 13 & 3 & 30 \\
A2B2 & 13 & 12 & 2 & 27 \\
\hline
\end{tabular}

Hasil uji Chi-square dengan taraf signigfikansi 5\% menunjukkan variasi varietas dan proses pra pengeringan berpengaruh nyata terhadap penilaian aroma teh cascara oleh panelis. Varietas kulit kopi yang digunakan dalam pembuatan teh cascara berpengaruh dalam menentukan aroma seduhan teh cascara. Aroma yang paling disukai yaitu sampel teh cascara A1B1 dengan perlakuan pengupasan kulit setelah pengeringan dan varietas Tugu Sari. Menurut Hulupi [4] varietas BP 42 memiliki aroma biji yang tidak tajam, sehingga panelis lebih menyukai aroma sampel teh cascara varietas Tugu Sari (A1) yang lebih menimbulkan aroma.

\section{J. Rasa Teh Cascara}

Persentase tingkat kesukaan panelis terhadap aroma teh cascara dengan variasi varietas dan proses pra pengeringan dapat dilihat pada Tabel 3 .
TABel III. Presentase TingKat KesukaAn Panelis DENGan SCORE Sangat TidaK SuKa HingGa Sangat SUKA TERHADAP RASA TEH CASCARA DENGAN VARIASI VARIETAS DAN PROSES PRA PENGERINGAN

\begin{tabular}{lcccc}
\hline Perlakuan & $\begin{array}{c}\text { Agak } \\
\text { suka } \\
(\%)\end{array}$ & $\begin{array}{c}\text { Suka } \\
(\%)\end{array}$ & $\begin{array}{c}\text { Sangat } \\
\text { suka }(\%)\end{array}$ & $\begin{array}{c}\text { Jumlah } \\
(\%)\end{array}$ \\
\hline A1B1 & 18 & 34 & 7 & 59 \\
AIB2 & 28 & 19 & 4 & 51 \\
A2B1 & 16 & 19 & 3 & 38 \\
A2B2 & 10 & 10 & 4 & 24 \\
\hline
\end{tabular}

Hasil uji Chi-square dengan taraf signigfikansi 5\% menunjukkan variasi varietas dan proses pra pengeringan berpengaruh nyata terhadap penilaian aroma teh cascara oleh panelis. Teh cascara A1B1 adalah teh cascara dengan perlakuan pengupasan kulit sebelum pengeringan dan varietas Tugu Sari. Hal ini dikarenakan pada analisa $\mathrm{pH}$ teh cascara varietas Tugu Sari lebih tinggi daripada varietas BP42, sehingga seduhan teh cascara yang dihasilkan tidak terlalu asam. Selain itu, berdasarkan analisa kadar kafein yang telah dilakukan teh cascara dengan varietas Tugu Sari memiliki kandungan kafein yang lebih sedikit daripada varietas BP42. Kandungan kafein dan tannin yang menyebabkan rasa pahit pada teh. Sampel teh cascara A1B1 memiliki rasa yang paling bisa diterima oleh indra perasa panelis karena memiliki rasa yang paling tidak asam dan tingkat rasa pahitnya paling rendah.

K. Keseluruhan teh cascara

Hasil uji Chi-square menunjukkan bahwa variasi varietas dan proses pra pengeringan berpengaruh nyata $(\alpha<0,05)$ terhadap penilaian keseluruhan teh cascara oleh panelis Persentase tingkat kesukaan panelis terhadap keseluruhan teh cascara dengan variasi varietas dan proses pra pengeringan dapat dilihat pada Tabel 4.

TABel IV. PRESENTASE TingKat KesukaAn PANElis DENGAN SCORE AgaK SuKa HingGa SANGAT SuKa TERHADAP KESElURUHAN TEH CASCARA DENGAN VARIaSI VARIETAS DAN PROSES PRA PENGERINGAN

\begin{tabular}{lcccc}
\hline Perlakuan & $\begin{array}{c}\text { Agak } \\
\text { suka } \\
(\%)\end{array}$ & $\begin{array}{c}\text { Suka } \\
(\%)\end{array}$ & $\begin{array}{c}\text { Sangat } \\
\text { suka } \\
(\%)\end{array}$ & $\begin{array}{c}\text { Jumlah } \\
(\%)\end{array}$ \\
\hline A1B1 & 31 & 22 & 10 & 63 \\
AIB2 & 20 & 25 & 5 & 50 \\
A2B1 & 22 & 16 & 4 & 42 \\
A2B2 & 19 & 9 & 1 & 29 \\
\hline
\end{tabular}

Persentase tingkat kesukaan panelis terhadap keseluruhan seduhan teh cascara (rentang skala agak suka - sangat suka) tertinggi pada sampel A1B1 yaitu $63 \%$ dan yang terendah sampel teh cascara A2B2 yaitu 29\%. Teh cascara A1B1 adalah sampel dengan perlakuan pengupasan sebelum pengeringan dan varietas Tugu Sari, sedangkan A2B2 adalah teh cascara perlakuan pengupasan kulit setelah pengeringan dan varietas BP 42. Hal ini sesuai dengan analisa yang telah dilakukan yaitu teh cascara A1B1 
Nurhayati, Maria Belgis, Danis Aprilia Neilasari. Karakteristik Fisikokimia dan Preferensi Cascara Terbuat dari Kulit Kopi Robusta var. Tugu Sari dan Bp 42

memiliki nilai tertingggi pada uji pereferensi parameter rasa dan aroma, sedangkan sampel A2B2 memiliki nilai terendah pada pada parameter rasa dan aroma.

\section{Uji Efektivitas}

Uji efektivitas bertujuan untuk memilih perlakuan terbaik. Uji efektivitas dalam penelitian ini dilakukan pada parameter total polifenol, aktivitas antioksidan, kadar kafein, dan parameter sensoris (rasa, aroma dan warna) sehingga menghasilkan satu perlakuan terbaik. Hasil uji efektivitas teh cascara disajikan pada Tabel 5.

Tabel V. Data Hasil Analisis Efektivitas Teh CASCARA

\begin{tabular}{ccccc}
\hline Perlakuan & A1B1 & A1B2 & A2B1 & A2B2 [4] \\
\hline $\begin{array}{c}\text { Nilai } \\
\text { efektivitas }\end{array}$ & 0,67 & 0,34 & 0,66 & 0,07 \\
\hline
\end{tabular}

Perlakuan terbaik teh cascara adalah A1B1 yaitu teh cascara varietas Tugu Sari dengan perlakuan pengupasan kulit sebelum pengeringan. Teh cascara A1B1 memiliki nilai total polifenol 10,65 GAE/mL; aktivitas antioksidan 70,12\%; kadar kafein 1,25\%; total asam tertitrasi 2,57\%; $\mathrm{pH} 3,76$; total padatan terlarut $2{ }^{\circ}$ Brix; kecerahan (L*) 27,48; kesukaan rasa $59 \%$; aroma 59\%; warna 44\% dan keseluruhan $63 \%$. Perlakuan terjelek adalah pada sampel A2B2 yaitu teh cascara varietas BP 42 dengan proses pengupasan setelah pengeringan. Sampel A2B2 memiliki nilai total polifenol 10,39 GAE/mL; aktivitas antioksidan 60,77\%; kadar kafein 1,15\%; total asam tertitrasi 1,98\%; $\mathrm{pH} 4,9$; total padatan terlarut 3,33 ${ }^{\circ}$ Brix; kecerahan (L*) 26,9; kesukaan rasa $24 \%$; aroma $27 \%$; warna $49 \%$ dan keseluruhan $29 \%$.

\section{KESIMPULAN}

Perbedaan proses pra pengeringan dan varietas kopi yang digunakan berpengaruh nyata terhadap sifat fisikokimia (total padatan terlarut, $\mathrm{pH}$, kecerahan, antioksidan dan kadar kafein) kecuali pada analisa total polifenol dan berpengaruh nyata pada semua uji preferensi teh cascara (warna, aroma, rasa dan keseluruhan). Perlakuan terbaik teh cascara adalah A1B1 (varietas Tugu Sari dengan perlakuan pengupasan kulit sebelum pengeringan) yang memiliki nilai total polifenol $10,65 \mathrm{GAE} / \mathrm{mL}$; aktivitas antioksidan 70,12\%; kadar kafein 1,25\%; total asam tertitrasi 2,57\%; $\mathrm{pH} 3,76$; total padatan terlarut $2{ }^{\circ}$ Brix; kecerahan (L*) 27,48; sensori rasa $59 \%$; aroma 59\%; warna $44 \%$ dan keseluruhan $63 \%$.

\section{UCAPAN TERIMA KASIH}

Penulis menyampaikan terima kasih kepada Universitas Jember melalui LP2M yang telah mendukung penelitian melalui Kelompok Riset Pangan ASUH (Aman, Sehat, Utuh, Halal). Terima kasih juga disampaikan kepada Gerai Jetos Natural \&
Healthy Products yang telah memasarkan produk cascara.

\section{DAFTAR PUSTAKA}

[1] Ardheniati, M. (2009). Kinetika Fermentasi Pada TehKombucha Dengan Variasi Jenis Teh Berdasarkan Pengolahannya. Surakarta: Fakultas Pertanian Universitas Sebelas Maret.

[2] Chun, O.K., Kim, D.O., dan Lee, C,Y. (2003). Superoxide Radical Scavenging Activity of The Major Polyphenols in Fresh Plums. Jurnal Agic Food Chem. 51: 8067-8072.

[3] Heeger, A.., Agniezka K.C., Ennio, C., Wilfried, A. (2016). Bioactives of coffee Cherry Pulp and its Utilisation for Production of Cascara Beverage. Jurnal Food Chemistry. 221: 969-975.

Hulupi, R. (2005). Determinasi Klon-Varietaskopi Robusta Dan Varietas Kopi Arabika. Jember: Pusat Penelitian Kopi dan Kakao Indonesia.

[5] Jacobo-Velazquez, D.A., and Cisneros-Zevallos, L. (2009). Correlations of Antioxidant Activity against Phenolic Content Revisited: A New Approach in Data Analysis for Food and Medicinal Plants. Journal of Food Science 74:9, 107-113

[6] Kurniawati, D. (2015). Karakteristik Fisik dan Kimia Biji Kakao Kering Hasil Perkebunan Rakyat di Kabupaten Gunung Kidul. Skripsi. Universitas Jember. Jember

[7] Lestario, L.N., M. K. W. C. Yoga., dan A.I. Kristijanto. (2014). Stabilitas Antosianin Jantung Pisang Kepok (Musa Paradisiaca L) terhadap Cahaya sebagai Warna Agar-Agar. Jurnal AGRITECH. 34(4): 374381.

[8] Londra, I.M. dan Andri. K.B. (2007). Potensi Pemanfaatan Limbah Kopi untuk Pakan Penggemukan Kambing Peranakan Etawah. Seminar Nasional Inovasi untuk Petani dan Peningkatan Daya Saing Produk Pertanian. Balai Pengkajian Teknologi Pertanian: 536-542.

[9] Lydia, S.W., Simon, B.W., dan Susanto, T. (2001). Ekstraksi dan Karakterisasi Pigmen dari Kulit Buah Rambutan (Nephelium Lappaceum). Var. Binjai Bioasin. 1(2): BP 42-53.

[10] Nurhayati, N. (2017). Karakteristik Sensori Kopi Celup Dan Kopi Instan Varietas Robusta Dan Arabika. Jurnal Ilmiah Inovasi. 17(2) : 80-85 